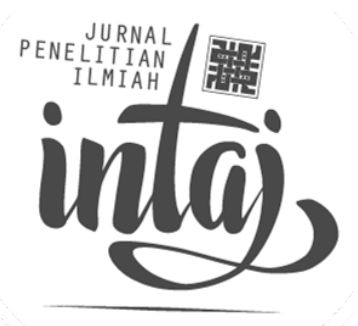

\title{
HUBUNGAN KOMUNIKASI INTERPERSONAL DAN PEMAAFAN DENGAN KEBAHAGIAAN SUAMI ISTRI
}

\author{
Nurhayati (nurhayati_thok@yahoo.com) ${ }^{1}$ \\ 1) IAI Al-Qolam Gondanglegi Malang
}

(Received: June 2017 / Revised: September 2017 / Accepted: September 2017)

\begin{abstract}
The objective of this study is to examine whether or not there is a correlation between interpersonal communication and forgiveness and spouses happiness. The subject of this study was 200 spouses in Malang regency. Interpersonal Communication Inventory (ICI) was used to measure interpersonal communication, Transgression-Related Interpersonal Motivation (TRIM) was used to measure forgiveness, and Oxford Happiness Inventory (OHI) was used to measure happiness. The result of the data analysis using multiple regression tests was that there is a positive and significant correlation between interpersonal communication and happiness, between forgiveness and happiness, between interpersonal communication and forgiveness and spouses happiness $(\mathrm{R}=.729, \mathrm{P}=0.000)$
\end{abstract}

Keywords: interpersonal communication, forgiveness, spouses happiness

\section{PENDAHULUAN}

Komunikasi interpersonal pasangan suami istri merupakan kesinambungan interaksi suami istri untuk memudahkan proses pengenalan satu dengan yang lainnya. Komunikasi positif terjadi apabila pasangan suami istri dapat berkomunikasi, berinteraksi, merasa saling diuntungkan, dan ditandai dengan adanya timbal balik yang serasi. Dengan keadaan ini, tujuan pernikahan yang sebenarnya dapat tercapai. 
Komunikasi interpersonal positif pasangan suami istri dapat tercapai melalui komunikasi yang efektif pasangan tersebut. Dikatakan efektif apabila komunikasi yang dilakukan pasangan suami istri, dapat mencapai tujuan pernikahan, yaitu memperoleh kebahagiaan. Komunikasi interpersonal yang efektif ini antara lain dengan saling memberikan pemahaman terhadap suami ataupun istri akan keinginan masing-masing. Hal ini akan memberikan kenyamanan bagi kedua belah pihak.

Komunikasi negatif terjadi apabila pasangan suami istri ada yang merasa diuntungkan dan ada yang merasa dirugikan atau terjadi ketidak selarasan. Apabila tidak ada keselarasan timbal balik antara pihak suami dan istri dalam berinteraksi tujuan dalam pernikahan tidak akan tercapai bahkan mengalami kendala. ${ }^{1}$ Komunikasi interpersonal negatif pasangan suami istri terjadi apabila komunikasi suami istri tersebut tidak efektif, yaitu gagal mencapai tujuan pernikahan. Komunikasi suami istri ini tidak efektif terjadi karena kegagalan pasangan untuk saling beradaptasi dan berkomunikasi dengan baik, persepsi terhadap pernikahan yang berbeda, faktor kepribadian, budaya, dan sistem asuh dalam keluarga yang berbeda. Semakin tinggi tingkat perbedaan, sulitnya titik temu dan pola komunikasi yang kurang baik dapat menimbulkan masalah yang berkepanjangan.

Salah satu akibat dari komunikasi interpersonal pasangan suami istri yang negatif adalah perselingkuhan. Perselingkuhan ini bisa terjadi baik pada pihak suami maupun pihak istri. Perselingkuhan ini berawal dari timbulnya rasa tidak nyaman pada pasangan suami istri sehingga mengakibatkan menurunnya tingkat kebahagiaan dalam pernikahan mereka. Keadaan ini mendorong pasangan suami istri tersebut mencari bentuk kebahagiaan lain seperti menjalin hubungan dengan selain pasa-ngan primernya.

Apabila dalam rumah tangga sudah terjadi hubungan suami istri yang negatif, misalnya karena ada perselingkuhan, maka rumah tangga pasangan suami istri ini sulit dipertahankan. Solusi dari permasalahan ini yang sering terjadi adalah perceraian, meskipun banyak pihak mengakui bahwa perceraian bukanlah hal yang cukup menyenangkan. Perceraian sering melalui proses yang panjang. Biasanya diawali dari miss communication yang kecil antara pasangan suami istri tersebut sehingga kesalahan yang tidak termaafkan.

Agar tidak terjadi perceraian, kedua pihak harus melakukan usaha pencegahan secara maksimal. Salah satu usaha yang dapat dilakukan pasangan suami istri ini adalah memperbaiki komunikasi interpersonal mereka. Bentuk konkretnya, pasa-

\footnotetext{
${ }^{1}$ D. Wisnuwardhani \& Fatmawari, Mashoedi Sri. Hubungan Interpersonal. Edisi I, (Jakarta: Salemba Humanika, 2012).
} 
ngan suami istri ini dapat melakukan tindakan saling memberikan maaf terhadap pasangan suami istri yang bersalah atau menyakiti pasangannya.

Pemaafan (forgiveness) ini dapat mengatasi luka batin akibat disakiti baik psikis maupun fisik. Pemaafan dapat menjadi salah satu cara untuk memfasilitasi penyembuhan luka dalam diri seseorang dan antar pribadi yang bermusuhan dan menyakiti, sedangkan Worthington menjelaskan jika orang yang tersakiti bisa memberi maaf, berarti ia melakukan pergantian emosi negatif (seperti marah atau takut) dari transgresi yang telah dipersepsikan individu atau keengganan untuk memaafkan (unforgiveness) kearah emosi positif (seperti empati, simpati, belas kasih, cinta). ${ }^{2}$

Dalam memaafkan, idealnya sikap dan perasaan negatif memang harus digantikan dengan sikap dan perasaan positif. Namun pada kenyataannya, hal ini tidak mudah dilakukan, apalagi secara cepat. Selalu ada persoalan psikologis di antara dua pihak yang pernah mengalami keretakan hubungan akibat suatu kesalahan. Memaafkan secara dewasa bukan berarti menghapus seluruh perasaan negatif tetapi menjadi sebuah keseimbangan perasaan. Keinginan untuk berbuat positif tidak berarti menghapuskan perasaan negatif yang pernah ada. Suatu keseimbangan akan dicapai jika hal yang positif dan negatif berkoeksistensi. Hal ini hanya dapat dicapai bila masing-masing individu mampu belajar menyadari bahwa setiap orang mempunyai kekurangan masing-masing. ${ }^{3}$ Peristiwa menyakitkan boleh jadi dilakukan oleh seorang teman tetapi mungkin dirinya juga turut berperan atas terjadinya peristiwa tersebut. Kesadaran seperti inilah yang lebih dibutuhkan daripada usaha membuat ilusi mengganti semua pengalaman negatif menjadi hal positif.

Pernikahan selain dapat menjadi sumber kebahagiaan dan kenyamanan bagi suami maupun istri,juga dapat menjadi sumber stres yang luar biasa. Kegagalan suami istri dalam berkomunikasi untuk saling menyesuaikan diri dan memecahkan masalahmasalah secara efektif dapat memicu masalah yang berkepanjangan. Kondisi pernikahan yang tidak menyenangkan dan banyaknya harapan yang tidak terpenuhi dapat memicu kekerasan dalam rumah tangga (KDRT). Dalam hal ini kekerasan yang dilakukan oleh suami maupun istri.

Banyak kekerasan yang terjadi dalam sebuah pernikahan, namun hanya sedikit yang terungkap. Fenomena ini seperti gunung es yang banyak sekali terjadi namun hanya sedikit yang terlihat. Tabu mengungkap permasalahan yang terjadi dalam pernikahan dan minimnya kesadaran untuk berkonsultasi kepada ahli ketika terjadi permasalahan adalah penyebab memburuknya hubungan suami istri dan berdampak pada

\footnotetext{
${ }^{2}$ E.L. Worthington, Jr., Forgiving and Reconciling: Bridges to Wholeness and Hope. Downers Grove, (IL: InterVarsity Press, 2003).

${ }^{3}$ Smedes, L. B. Forgive and forget: Healing the Hurts We Don't Deserve. (New York: Harper \& Row. 1984).
} 
terjadinya kekerasan dalam rumah tangga. Kekerasan dalam pernikahan tidak hanya terjadi pada fisik tetapi bisa juga terjadi pada psikis, ${ }^{4}$ meskipun beberapa teori melihat kekerasan rumah tangga berakar pada masalah tertentu. ${ }^{5}$

Kebahagiaan adalah harapan dari setiap pasangan yang sudah menikah. Tetapi tidak jarang dalam upaya mencari kebahagiaan tersebut menghadapi kendala. Kegagalan dalam menjalin komunikasi dengan pasangan merupakan salah satu penyebab tidak tercapainya kebahagiaan. Perasaan positif akan mendorong seseorang untuk melakukan tindakan positif, seperti membangun hubungan yang positif dengan pasangan, memiliki pikiran yang optimis, memiliki keluarga yang harmonis, mensyukuri apa yang dimiliki, menghargai dan menghormati pasangan serta berterima kasih, unsur-unsur inilah yang membuat seseorang memiliki kebahagiaan sejati. ${ }^{6}$

Kebahagiaan Dalam Perkawinan (Marital Happiness) merujuk kepada perasaan yang dialami seseorang dalam perkawinannya. Kebahagiaan adalah konsep yang sukar difahami sehingga tidak ada yang dapat menyeimbangkan antara 'perasaan bahagia' dan 'perasaan tidak bahagia'. Kesukaran ini disebabkan karena ia berhubungan dengan emosi yang kompleks di dalam diri seseorang. ${ }^{7}$

Diener \& Oishi, menyatakan bahwa faktor demografis berkorelasi dengan kebahagiaan. ${ }^{8}$ Sejauh mana faktor demografis tertentu dapat meningkatkan kebahagiaan tergantung dari nilai dan tujuan yang dimiliki seseorang, kepribadian dan kultur. Secara umum, Diener mengatakan bahwa efek faktor demografis (misalnya pendapatan, pengangguran, status pernikahan, umur, jenis kelamin, pendidikan, ada tidaknya anak) terhadap kebahagiaan biasanya kecil. Faktor demografis membedakan antara orang yang sedang-sedang saja dalam merasakan kebahagiaan (tingkat kebahagiaan sedang) dan orang yang sangat bahagia (tingkat kebahagiaan tinggi). Tujuan dari penelitian ini adalah untuk mengetahui hubungan antara komunikasi interpersonal dengan pemaafan terhadap kebahagiaan suami istri.

\footnotetext{
4 Johnson, M. P. "Patriarchal Terrorism and Common Couple Violence; Two Forms of Violence Against Women". Journal of Marriage and the Family, 57, 283-294.

${ }^{5}$ McKenry, B. C., Julian, T. W., \& Gavazzi, S. M. Toward a Biopsychosocial Model of Domestic Violence. Journal of Marriage and Family. 57, 307-320. 1995.

${ }^{6}$ Seligman, M. E. P. Authentic Happiness. (tnp: Free Press. 2002).

${ }^{7}$ Terman, L. M. Psychological Factors in Marital Happiness. (New York: McGraw-Hill. 1938)

${ }^{8}$ Diener \& Oishi. Subjective Well Being: The Science of Happiness and Life Satisfaction. In C. R Synder \& S. J Lopez (Eds), Handbook of Possitive Psychology, ed. II, (New York, NY: Oxford University press. 2005), hlm. 63-73
} 


\subsection{Hubungan Komunikasi Interpersonal dan Kebahagiaan}

Komunikasi interpersonal adalah proses pengiriman dan penerimaan pesan antara dua orang atau lebih secara langsung atau bertatap muka. Komunikasi interpersonal merupakan komunikasi yang paling ampuh dalam usaha untuk mengubah opini, kepercayaan ideologis. Ketika komunikan memberi jawaban, ia menjadi enconder dan komunikan menjadi deconder. Dalam kehidupan sehari-hari, komunikasi sangat penting agar kedua pihak dapat mengerti bahasa yang digunakan juga mengenai makna yang diucapkan. Komunikasi, selain proses informatif, juga mengandung proses persuasif. Lasswell juga menyatakan bahwa komunikasi adalah proses penyampaian pesan oleh komunikator kepada komunikan melalui media yang menimbulkan efek tertentu. ${ }^{9}$

Bentuk komunikasi yang paling sederhana adalah komunikasi interpersonal. Disadari atau tidak setiap hari seseorang melakukan komunikasi interpersonal dengan orang lain termasuk suami dengan istrinya dan sebaliknya. Fitrah manusia sebagai mahluk sosial dalam memenuhi kebutuhan hidupnya memerlukan kerjasama dengan manusia lain. Ingin punya teman dan hidup berkelompok. Hal ini sesuai dengan teori Maslow (1943) yang ketiga yaitu berhubungan atau kebutuhan sosial yaitu kebutuhan untuk berafiliasi dan diterima dalam berbagai kelompok.

Burleson mengatakan bahwa hubungan antara komunikasi interpersonal dan kebahagiaan dalam pernikahan bukanlah hal yang sedehana dan gamblang, melainkan bersifat kompleks dan variatif. ${ }^{10}$ Beberapa faktor seperti jenis komunikasi, permasalahan dalam pernikahan, gender dan unit analitik (pasangan, diri sendiri dan orang lain) berpengaruh terhadap keefektifan berkomunikasi. Komunikasi interpersonal efek yang didapatkan merupakan efek paling kuat dibanding efek komunikasi yang lain. Dalam komunikasi interpersonal ini, komunikator mempengaruhi secara langsung tingkah laku komunikannya, memanfaatkan pesan non verbal dan verbal serta menyesuaikan pesannya bila yang didapat umpan balik negatif. ${ }^{11}$

Sebuah penelitian menyebutkan bahwa komunikasi interpersonal berhubungan dengan kebahagiaan dalam perkawinan untuk pasangan yang tidak bermasalah, namun tidak bagi pasangan yang bermasalah. ${ }^{12}$ Selain itu, komunikasi interpersonal bagi suami istri juga merupakan salah satu jalan untuk mengenal satu sama lain,

\footnotetext{
${ }^{9}$ Effendy, Hubungan Masyarakat Suatu Study Komunikologis, (Bandung: Remaja Rosdakarya. 2002).

10 Burleson, Brant R;Denton, Wayne H. The Relationship Between Communication Skill and Marital Satisfaction: Some Moderating Effects, Journal of Marriage and the Family; 59, 4;884902. 1997.

11 Vardiansyah, Dani. Pengantar Ilmu Komunikasi, (Bogor: Ghalia Indonesia. 2004).

12 Burleson, Brant R;Denton, Wayne H. The Relationship between...
} 
belajar mengenal kebiasaan satu sama lain, sarana untuk mencapai kesepakatan dan cara untuk mengatasi konflik pasca pernikahan. ${ }^{13}$

Komunikasi interpersonal terjadi dalam beberapa situasi, yaitu: pertama, sapaan (phatic communion). Sapaan mempunyai arti yang penting bagi komunikasi interpersonal suami istri. Sapaan mencerminkan suatu penghargaan terhadap pasangan, menunjukkan indeks kelekatan dan sebagai sifat, sikap dan nilai perilaku seseorang.

Kedua, wawancara (interview). Selama ini, wawancara dikenal sebagai tanya jawab yang digunakan dalam pengangkatan pegawai dan dalam situasi formal. Padahal wawancara punya makna yang sangat luas. Dua orang yang sedang bercakap-cakap yang mempunyai tujuan tertentu seperti suami berbicara dengan istrinya dapat dikatakan sebagai wawancara informasional (informational interview). Informational interview yang dilakukan suami istri adalah wawancara yang mempunyai tujuan untuk memperoleh keterangan tentang satu sama lain, menentukan bagaimana pasangan harus bersikap terhadap satu sama lain. Wawancara informasional ini terdiri dari sederetan pertanyaan yang saling berkaitan yang mengarah kepada keinginan untuk memperoleh informasi lebih dalam.

Ketiga, bersahabat dan berteman. Bersahabat dan berteman merupakan hal yang sangat penting dalam berumah tangga. Perasaan mempunyai teman dan memiliki sahabat dalam mengarungi bahtera rumah tangga akan memberikan kenyamanan dalam berkomunikasi dengan pasangan.

Keempat, bermusuhan dan bersaing. Persaingan dalam rumah tangga sering terjadi tanpa disadari oleh pasangan, baik bersaing dalam merebut perhatian anak maupun dalam mendapatkan penghasilan. Dalam berumah tangga, sebagian besar waktu dihabiskan untuk berkomunikasi dengan pasangan yang berasal dari latarbelakang yang berbeda. Bila komunikasi yang dilakukan pasangan saling memandang rendah satu sama lain akan timbul perasaan saling tidak menyukai satu sama lain, hal ini yang mengakibatkan munculnya permasalahan.

Penelitian menunjukkan bahwa masalah komunikasi interpersonal adalah sumber utama kesulitan suami istri, yang berawal dari kesalahpahaman dan komunikasi interpersonal yang tidak efektif yang berakibat kemarahan dan frustasi ketika harapan tidak sesuai dengan kenyataan. ${ }^{14}$ Kemarahan yang terjadi dapat mengakibatkan perbuatan yang menyakiti hati pasangan, dan pemaafan akan sulit dilakukan ketika komunikasi yang terjadi antara kedua belah pihak tidak efektif. Komunikasi akan berjalan efektif apabila ketepatan (fidelity) dapat ditingkatkan dan ganggu-annya (noise) dapat diperkecil. Sebagai tanda bahwa komunikasi yang dilakukan pasangan

\footnotetext{
${ }^{13}$ Wisnuwardhani, D \& Fatmawati, Mashoedi Sri. Hubungan Interpersonal...

${ }^{14}$ Okun, B. F. Effective Helping, Interviewing, and Counseling Techniques, Ed. III (Monterey, CA: Brooks/Cole, 1991).
} 
suami istri efektif adalah: kesenangan, pengertian, mempengaruhi sikap, tindakan dan hubungan sosial yang baik. Komunikasi interpersonal akan efektif apabila memperhatikan faktor-faktor seperti empati, keterbukaan, dukungan, kepo-sitifan dan kesamaan.

\subsection{Hubungan Pemaafan dan Kebahagiaan}

Menurut Maltby dkk., pemaafan merupakan upaya untuk membawa perasaan negatif dan menggantinya dengan pikiran, perasaan, dan tindakan positif. ${ }^{15}$ Beberapa penelitian menemukan bahwa meminta maaf sangat efektif dalam mengatasi permasalahan komunikasi interpersonal, karena permintaan maaf merupakan sebu-ah penyataan tanggung jawab tidak bersyarat atas kesalahan dan sebuah komitmen untuk memperbaikinya. ${ }^{16}$

Pemaafan memiliki manfaat baik intrapersonal maupun interpersonal dengan melepaskan kemarahan dan kebencian serta mendorong pemulihan hubungan yang rusak setelah peristiwa menyakitkan. ${ }^{17}$ Pada saat yang sama, pengampunan mengurangi tekanan psikologis korban, seperti kemarahan, kepahitan dan kecemasan, serta membantu untuk melepaskan perasaan sakit. ${ }^{18}$

Mccullough dkk. menjelaskan bahwa pemaafan adalah proses perubahan tiga dorongan dalam diri individu terhadap pelaku. Tiga dorongan tersebut adalah avoidance motivation, revenge motivation, dan benevolence motivation, yang selanjutnya menjadi indikator dalam pemaafan. ${ }^{19}$ Penjelasan dari ketiga indikator yang mendasari pemaafan ialah sebagai berikut: pertama keinginan menghindar (avoidance motivations) ditandai dengan individu yang menghindari atau menarik diri (withdrawl) dari pelaku; kedua, keinginan membalas dendam (revenge motivation) ditandai dengan dorongan individu untuk membalas perbuatan pelaku yang ditunjukkan kepadanya. Dalam kondisi ini individu tersebut marah dan berkeinginan untuk membalas dendam terhadap pelaku, ketika individu dilukai oleh pelaku, maka

15 Maltby J, Day L, \& Louise Barber. "Forgiveness and Happiness: The Differing Contexts Of Forgiveness Using The Distinction Between Hedonic And Eudaimonic Happiness". Journal of Happiness Studies 6, 1-13, 2005.

${ }^{16}$ Darby, B.W. and Schlenker, B. R. Children Reactions to Apologies. Journal of Personality and Social Psychology, 1982. 43 (4), 742-753.

${ }^{17}$ Freedman, S. R., \& Enright, R. D. "Forgiveness as An Intervention Goal with Incest Survivors", Journal of Consulting and Clinical Psychology, 1996. 64, 983-992. McCullough, M. E.

"Forgiveness as Human Strength: Theory, Measurement, and Links to Well-Being", Journal of Social and Clinical Psychology, 19(1), 2000. 43-55.

18 Enright, R. D., Gassin, E. A., \& Wu, C. "Forgiveness: A Development View”, Journal of Moral Education, 2, 1992. 99-114.

${ }^{19}$ McCullough, M. E. "Forgiveness as...". 
yang terjadi adalah peningkatan dorongan untuk menghindar (avoidance) dan membalas dendam (revenge). Ketiga, keinginan berbuat baik terhadap pelaku (benevolence motivation) ditandai dengan dorongan untuk berbuat baik terhadap pelaku. Dengan adanya keinginan berbuat baik terhadap pelaku (benevolence motivation), berarti juga menghilangkan kehadiran dua indikator sebelumnya. Oleh karena itu, individu yang memaafkan memiliki keinginan berbuat baik terhadap pelaku (benevolence motivation) yang tinggi, namun di sisi lain memiliki keinginan menghindar (avoidance motivation) dan keinginan membalas dendam (revenge motivation) yang rendah.

Penelitian yang dilakukan oleh Maltby dkk. menyebutkan bahwa pemaafan memberikan pengaruh yang besar pada kebahagiaan. ${ }^{20}$ Pemaafan sebagai upaya untuk mengatasi perasaan sebagai akibat dari pelanggaran dan untuk mengatasi perasaan negatif yang terkait dengan pelanggaran itu. Sebagian besar penelitian mengatakan pemaafan dipusatkan pada konsekuensi negatif dari kegagalan untuk memaafkan, atau hambatan untuk memaafkan. Dengan demikian, kemarahan, kecemasan, depresi, permusuhan, dan kebencian semuanya telah dikaitkan dengan rendahnya tingkat pemaafan.

McCullough menyebutkan faktor-faktor yang mempengaruhi pemaafan ada dua yaitu faktor internal (personal) dan eksternal (situasional). Faktor internal yang mempengaruhi pemaafan yaitu: pertama, kepribadian. Bentuk kepribadian Narcissistic entilement yang menekankan asumsi yang dimiliki seseorang tentang bagaimana orang lain seharusnya memperlakukan dirinya akan cukup sulit memaafkan dan lebih kepada pembayaran kembali terhadap apa yang terjadi di masa lalu. Individu ini mempunyai harapan mendapatkan perlakuan istimewa dengan mem-pertahankan hak-hak mereka. Kedua, perenungan kejadian masa lalu (rumination) dan penekanan (supression). Memaafkan akan jauh lebih sulit bagi orang yang lebih merenungkan tentang perasaan sakit hati. Sebaliknya, orang yang kurang merenungkan tentang sakit hati dan supresi akan tampak lebih memaafkan. ${ }^{21}$ Ketiga, mekanisme pertahanan diri (defense style). Karena mekanisme pertahanan diri menghambat pemaafan, maka dibutuhkan lebih dari sekedar tidak adanya perasaan, sikap dan kognisi negatif tentang pelanggaran. Selain itu perlu pengelolaan ide-ide positif dan perilaku. Kemungkinan dan kehadiran dari sikap, perilaku dan koqnisi pemaafan positif bukan berati tidak adanya pemaafan negatif, berhubungan dengan gaya pertahanan neurotic (undoin, pseudoaltruism, idealization formation). ${ }^{22}$ Keempat, empati. Istilah empati mengacu pada apa yang dirasakan orang lain, pe-

\footnotetext{
${ }^{20}$ Maltby J, Day L, \& Louise Barber, "Forgiveness and...".

${ }^{21}$ McCullough, M.E., Wortington, E. L., et.al. "Interpersonal Forgiving in Close Relationships: II. Theoritical Elaboration and Measurement". Journal of Personality and Social Psychology, 75, (6), 1998. 1586-1603.

22 Maltby J, Day L, \& Louise Barber. "Forgiveness and..."
} 
rasaan apa yang dilakukan pada orang lain, dan merespon dengan belas kasih terhadap penderitaan orang lain. Keparalelan pemaafan dan empati berdasarkan pada respon kognitif, afektif dan perilaku yang menyertai suatu serangan interpersonal.

Faktor eksternal yang mempengaruhi pemaafan yaitu: pertama, permintaan maaf (apology). Pengakuan yang meliputi permintaan maaf, perasaan berdosa yang mendalam, menyalahkan diri, penyesalan dan perbaikan atas serangan yang dila-kukan penyerang menyebabkan korban memberi evaluasi lebih positif dan lebih memberikan maaf. Kedua, beratnya serangan (offense severity). Beratnya serangan yang dialami dapat mempengaruhi sejauh mana individu dapat memaafkan suatu pelanggaran. ${ }^{23}$ Beratnya serangan dapat berpengaruh pada bagaimana korban menafsirkan suatu permintaan maaf. Ketiga, tingkat pembangkitan (arousal). McCullough \& Witliev menunjukkan dalam penelitian eksperimen bahwa tingkat arousal yang dialami berhubungan dengan tingkat pembalasan dan permintaan maaf korban. ${ }^{24}$ Ketika individu berada pada tingkat arousal yang tinggi meskipun ada permintaan maaf dan penjelasan-penjelasan yang meredakan, permusuhan dan pembalasan tetap menjadi tinggi.

Proses pemaafan dibagi menjadi empat tahap, yaitu: pertama, membalut sakit hati. Sakit hati yang dibiarkan berarti merasakan sakit tanpa mengobatinya sehingga lambat laun akan mengrogoti kebahagian dan kententeraman. Oleh karena itu, meredakan dan memadamkan kebencian terhadap seseorang yang menyakiti bila dibalut, apalagi ditambah dengan obat, ibaratnya memberi antibiotik untuk mematikan sumber sakit.

Kedua meredakan kebencian. Kebencian adalah respon alami seseorang terhadap sakit hati yang mendalam dan kebencian yang memerlukan penyembuhan. Kebencian sangat berbahaya kalau dibiarkan berjalan terus. Tidak ada kebaikan apapun yang datang dari kebencian yang dimiliki seseorang. Kebencian sesungguhnya melukai si pembenci sendiri melebihi orang yang dibenci. Kebencian tidak bisa mengubah apapun menjadi lebih baik bahkan kebencian akan membuat banyak hal menjadi lebih buruk. Dengan berusaha memahami alasan orang lain menyakiti atau mencari dalih baginya atau instropeksi sehingga ia dapat menerima perlakuan yang menyakitkan maka akan berkurang atau hilanglah kebencian itu.

Ketiga, upaya penyembuhan diri sendiri. Seseorang tidak mudah melepaskan kesalahan yang dilakukan orang lain. Akan lebih mudah dengan jalan melepaskan orang itu dari kesalahannya dalam ingatannya. Kalau ia bisa melepaskan kesalahan dalam

${ }^{23}$ Boon, S.D., \& Sulsky, L.M. "Attribution of Blame and Forgiveness in Romantic Relationships: a Policy-Capturing Study", Journal of Social Behavior and Personality. 12. 1997. 19-44.

${ }^{24}$ McCullough, M. E.,\& Witvliet, C. V. The Psychology of Forgiveness, dalam

C. R. Snyder \& S. L. Lopez (Eds.), Handbook of Positive Psychology, (NewYork: Oxford University Press. 2002), hlm. 446-458. 
ingatan, berarti ia memperbudak diri sendiri dengan masa lalu yang menyakitkan hati. Kalau ia tidak bisa membebaskan orang lain dari kesalahannya dan melihat mereka sebagai orang yang kekurangan sebagaimana adanya berarti membalikkan masa depannya dengan melepaskan orang lain dari masa lalu mereka. Memaafkan adalah pelepasan yang jujur walaupun hal itu dilakukan di dalam hati. Pemberi maaf sejati tidak berpura-pura bahwa mereka tidak menderita dan tidak berpura-pura bahwa orang yang bersalah tidak begitu penting. Asumsinya, memaafkan adalah melepaskan orang yang bersalah serta berdamai dengan diri sendiri dan orang lain.

Keempat, berjalan bersama. Dua orang yang berjalan bersama setelah bermusuhan memerlukan ketulusan. Pihak yang menyakiti harus tulus menyatakan kepada pihak yang disakiti dengan tidak akan menyakiti hati lagi. Pihak yang disakiti perlu percaya bahwa pihak yang meminta maaf menepati janji yangdibuat. Mereka juga harus berjanji untuk berjalan bersama di masa yang akan datang dan saling membutuhkan satu sama lain. Proses memaafkan adalah proses yang berjalan perlahan dan memerlukan waktu. ${ }^{25}$ Semakin parah rasa sakit hati semakin lama pula waktu yang diperlukan untuk memaafkan. Kadang-kadang seseorang melakukannya dengan perlahan-lahan sehingga melewati garis batas tanpa menyadari bahwa dia sudah melewatinya. Proses juga dapat terjadi ketika pihak yang disakiti mencoba mengerti kenapa hal itu terjadi bersama-sama dengan upaya meredakan kemarahan.

Menurut McCullough, secara teoritis, pemaafan dipengaruhi oleh empat faktor. Keempat faktor tersebut berada dalam satu kontinum, yaitu dari faktor yang paling mempengaruhi pemaafan sampai dengan faktor yang pengaruhnya tidak begitu besar. Keempat faktor tersebut adalah: (a) Faktor sosial-kognitif. Pemaafan dipengaruhi oleh pikiran dan perasaan individu terhadap peristiwa menyakitkan yang dialami dan terhadap pelakunya; (b) Karakteristik peristiwa yang menyakitkan. Persepsi terhadap tingkat keparahan dari peristiwa yang menyakitkan dan konsekuensinya akan mempengaruhi pemaafan individu; (c) Kualitas hubungan interpersonal. Dalam situasi menyakitkan, kualitas hubungan interpersonal adalah salah satu faktor penting dalam menentukan pemaafan. Hal ini dikarenakan pemaafan dapat dipahami sebagai perubahan motivasi ke arah hubungan yang lebih konstruktif setelah peristiwa yang menyakitkan terjadi; (d) Karakteristik kepribadian dari kontinum faktor yang mempengaruhi pemaafan. ${ }^{26}$

Pemaafan juga terkait dengan komunikasi dan pemecahan masalah. Sebagai contoh, Fincham dan Beach menunjukkan bahwa pemaafan berhubungan positif dengan komunikasi yang konstruktif dalam hubungan dan berhubungan negatif dengan

\footnotetext{
25 Smedes, L.B. Forgive and forget....

${ }^{26}$ McCullough, M.E. (2000). "Forgiveness as...".
} 
agresi psikologis. ${ }^{27}$ Selain itu, Karremans \& Van Lange menemukan bahwa pengampunan memprediksi dan mengembalikan motivasi sebelum berhubungan dan perilaku. ${ }^{28}$ Hasil studi mereka menunjukkan bahwa tingkat pemaafan diprediksi motivasi sebuah hubungan, terlepas dari tingkat komitmen terhadap pelaku. Fincham dan rekan-rekannya telah menunjukkan bahwa pengampunan pada pasangan yang sudah menikah dikaitkan dengan pemecahan masalah yang lebih baik. ${ }^{29}$

Kebahagiaan (happiness) merupakan konsep yang mengacu kepada emosi positif yang dirasakan individu. Individu yang merasakan kebahagiaan sejati (autentik) yaitu individu yang telah dapat mengolah dan mengidentifikasi kekuatan dasar yang dimilikinya dan digunakan pada kehidupannya sehari-hari. Kebahagiaan juga merupakan hasil upaya-upaya mencapai aktualisasi diri Proses yang menunjukkan bakat, kebutuhan, dan keyakinan tentang nilai-nilai terdalam mengarahkan cara hidup seseorang. ${ }^{30}$

Ada dua konsep kebahagiaan menurut Ryan \& Deci (2001). Pertama adalah kebahagiaan hedonis, Konsep ini menggambarkan pandangan bahwa kebahagiaan itu didasarkan pada kenikmatan yang subyektif. Kedua konsep kebahagiaan eudamonis. Konsep ini mengambarkankebahagiaan untuk realisasi diri, yaitu kebahagiaan sebagai hasil proses perkembangan dan ekspresi potensi diri terdalam (inner potential / daimon), (bakat, kepribadian, dan nilai). ${ }^{31}$

Faktor yang turut berperan pada tinggi rendahnya kebahagiaan seseorang adalah pernikahan. Survey besar menunjukkan kebahagiaan yang lebih besar kepada orang-orang yang menikah dibandingkan dengan mereka yang belum menikah atau yang pernah menikah kemudian bercerai, dipisahkan atau janda. Pernikahan dan kebahagiaan berkorelasi secara signifikan bahkan ketika usia dan pendapatan dikontrol. Diener dkk. menemukan bahwa pernikahan menawarkan manfaat lebih besar bagi laki-laki daripada perempuan dari segi emosi positif. ${ }^{32}$ Pernikahan juga

\footnotetext{
${ }^{27}$ Fincham, F. D., \& Beach, S. R. H. "Forgiveness in Marriage: Implications for Psychological Aggression and Constructive Communication", Personal Relationships, 9, 2002. 239-251.

28 Karremans, J. C., \& Van Lange, P. A. M. "Back to Caring After Being Hurt: The Role of Forgiveness", European Journal of Social Psychology, 34. 2004. 207-227.

29 F. D., Fincham, et.al.,. "Forgiveness and Conflict Resolution in Marriage, Journal of Family Psychology, 18, 2004, 72-81.

30 Seligman, M. E. P. Authentic Happiness....

31 Ryan, R. M., \& Deci, E. L. “On Happiness and Human Potentials: A Review of Research on Hedonic And Eudaimonic Well-Being”, Annual Review of Psychology, 52, 2001. 141-166.

32 Diener, E., et. al. "Similarity of the Relations Between Marital Status and Subjective Well-Being Across Cultures", Journal of Cross-Cultural Psychology, 31 (4), 1998. 419-436.
} 
menjadi pengalaman hidup yang signifikan pada $90 \%$ orang diseluruh dunia. ${ }^{33} \mathrm{Se}-$ buah penelitian menemukan bahwa gender bertanggung jawab atas kurang dari $1 \%$ varians dalam kebahagiaan tapi lebih dari $13 \%$ perbedaan dalam intensitas pe-ngalaman emosional. Perempuan rata-rata terbuka terhadap pengalaman emosional yang kuat, menciptakan kerentanan terhadap depresi yang diberikan oleh banyaknya peristiwa-peristiwa buruk, tetapi juga menciptakan peluang untuk tingkat intens kebahagiaan atas peristiwa yang baik. ${ }^{34}$

Papalia, Olds \& Feldman, menambahkan bahwa pernikahan menyediakan keintiman, komitmen, persahabatan, cinta dan kasih sayang, pemenuhan seksual, pertemanan, dan kesempatan untuk pengembangan emosional seperti sumber baru bagi identitas dan harga diri. ${ }^{35}$ Hal tersebut merupakan sumber dari kebahagiaan dalam mengarungi bahtera rumah tangga selain materi. Kebahagiaan diukur dengan dengan cara yang berbeda oleh setiap pasangan. Ada yang mengukur sebatas pencapaian materi dan merasa cukup setelah sampai di sana, namun ada yang beranggapan pencapaian kebahagiaan berbasis materi tidak akan memberikan kebahagiaan sejati.

Hakikat kebahagiaan bagi sebagian besar orang terletak pada nilai materi yang berlimpah seperti kedudukan, harkat, martabat, pangkat, dan kekayaan harta bahkan nama yang terkenal. Oleh karena itu setiap pasangan suami istri selalu berfikir dan berusaha untuk memperolehnya. Masing-masing pasangan punya gambaran kebahagiaan yang berbeda, begitu pula suami istri punya persepsi tentang kebahagiaan yang terkadang tidak sama. Hal inilah yang perlu di jembatani dengan komunikasi supaya suami istri dapat mencapai tujuan yaitu kebahagiaan karena satu sama lain saling memahami satu konsep yang sama.

Kebahagiaan sebagai penilaian subyektif dan global dalam menilai diri sebagai orang yang bahagia atau tidak. Hal ini berangkat dari pemikiran bahwa kebahagiaan dinilai berdasarkan kriteria-kriteria subyektif yang dimiliki individu. Seseorang bisa saja merasakan ketidakbahagiaan dalam hidupnya walaupun hidupnya dikelilingi oleh segala kenyamanan, cinta, dan kesejahteraan. Sebaliknya seseorang bisa saja tetap merasakan kebahagiaan walaupun hidupnya penuh dengan rintangan, tragedi, ketidaksejahteraan, dan tidak adanya cinta. Hal ini membuktikan bahwa sumbersumber kebahagiaan itu sangat personal dan bervariasi dari satu individu ke individu lainnya. Hingga saat ini masih terdapat perbedaan pendapat mengenai sumber

\footnotetext{
33 Diener, E., et. al. "The Evolving Concept of Subjective Well-Being: the Multifaceted Nature of Happiness", Advances in Cell Aging and Gerontology, 15, 2003. 187-219.

${ }^{34}$ Eddington, n. \& Shuman, r. Subjective Well-Being (Happiness): Continuing Psychology Education: 6 Continuing Education Hours. 2005.

35 D.E.,Papalia, et.al. Human Development, (New York: McGraw. 2004).
} 
dan penyebab kebahagiaan. Sejumlah pakar mengidentikkan kebahagiaan dengan waktu dan pengalaman hidup yang menyenangkan. Pada penelitian lain juga disebutkan bahwa prediktor kebahagiaan adalah perasaan optimis dan keinginan untuk berada di dekat orang lain. Selain itu merasakan suasana hati yang baik dan terpuaskan dalam kehidupan.

\subsection{Hipotesis}

Berdasarkan landasan teori di atas, maka hipotesis penelitian yang diajukan adalah:

1) Ada hubungan positif antara komunikasi interpersonal dengan kebahagiaan.

2) Ada hubungan positif antara pemaafan dengan kebahagiaan.

3) Ada hubungan positif antara komunikasi interpersonal dan pemaafan dengan kebahagiaan.

\section{METODE PENELITIAN}

\subsection{Subyek penelitian}

Subyek penelitian ini adalah pasangan suami istri dengan masa pernikahan lebih dari 5 tahun sebanyak 100 pasangan. Usia pernikahan yang lebih dari lima tahun telah melewati masa-masa krisis atas penyesuaian peran oleh masing-masing pasangan, tanggung jawab, serta penyesuaian tersebut mencegah kebingungan dan rasa cemas. ${ }^{36}$ Masa perkawinan lebih dari 5 tahun telah melewati masa krisis yang menentukan keberhasilan perkawinan. Subyek dipilih dengan sampling insidental dan bertempat tinggal di Kabupaten Malang.

${ }^{36}$ EB. Hurlock, Psikologi Perkembangan: Suatu Pendekatan Sepanjang Rentang Kehidupan, Edisi V, (Jakarta: Erlangga, 2000). 
Tabel 1: Deskripsi Subyek Penelitian (N=200)

\begin{tabular}{clll}
\hline Karakteristik Responden & Istri & Suami & Total \\
\hline Usia pernikahan & & & \\
\hline$>10$ tahun & $30(30 \%)$ & $30(30 \%)$ & $60(30 \%)$ \\
\hline $11-20$ tahun & $53(53 \%)$ & $53(53 \%)$ & $106(53 \%)$ \\
\hline $21-30$ tahun & $17(17 \%)$ & $17(17 \%)$ & $34(17 \%)$ \\
\hline Pendidikan & & \\
\hline SMP & $5(5 \%)$ & $11(11 \%)$ & $16(8 \%)$ \\
\hline SMA & $39(39 \%)$ & $46(46 \%)$ & $85(42,5 \%)$ \\
\hline Diploma & $35(35 \%)$ & $31(31 \%)$ & $66(33 \%)$ \\
\hline Sarjana & $21(21 \%)$ & $12(12 \%)$ & $33(16,5 \%)$ \\
\hline
\end{tabular}

Dari 100 pasang suami istri yang menjadi sampel pada penelitian ini diketahui usia pernikahan paling muda adalah selama 6 tahun sedangkan usia pernikahan paling tua adalah 30 tahun. Rata-rata pasangan suami istri ini telah menikah selama 14,83 tahun (15 tahun). Sedangkan tingkat pendidikan subyek mulai SMP hingga Sarjana, sebagian besar suami istri adalah berpendidikan sarjana.

\subsection{Variabel dan Instrumen Penelitian}

Interpersonal communication inventory (ICI) digunakan untuk mengukur komunikasi interpersonal. ${ }^{37}$ Pada skala ini ada 40 item pernyataan yang meliputi lima aspek yaitu self concept, ability, skill experience, emotion, self disclosure. Alat ukur ini tersusun atas 40 item dengan tiga pilihan jawaban yaitu ya, tidak, dan kadangkadang. Skor ICI terdapat 37 item valid, Skor ICI berada pada rentangan $37-111$. Skor ICI yang tinggi menunjukkan 111 skor ICI rendah menunjukkan 37. Dari hasil uji reabilitas kepada pasangan suami istri diperoleh nilai Alpha Cronbach 0,758.

Transregression-Related Interpersonal Motivation (TRIM) Inventory digunakan untuk mengukur pemaafan (forgiveness) berdasarkan tiga indikator yaitu pembalasan (revenge), penghindaran (avoidance) dan dorongan berbuat baik (Benevolence). ${ }^{38}$ Alat ukur ini tersusun atas 18 item dengan 4 pilihan jawaban yaitu: sangat tidak setuju, tidak setuju, netral, setuju. Skor TRIM terdapat 37 item valid, Skor TRIM berada pada rentangan 18-72. Skor TRIM yang tinggi menunjukkan 54 skor

\footnotetext{
37 M.J. Bienvenu, Interpersonal Communication Infentory, (tnp: University Associates. Inc. 1987).

38 McCullough, et al.,1998. "Interpersonal Forgiving....
} 
TRIM rendah menunjukkan 18. Berdasarkan hasil uji validitas kepada pasangan suami istri diketahui bahwa semua item valid dan dari hasil uji reabilitas diperoleh nilai Alpha Cronbach 0,807.

Oxford Happiness Inventory (OHI) digunakan untuk mengukur kebahagiaan (happiness) berdasarkan frekuensi dari afek positif atau kegembiraan; level dari kepuasan pada suatu periode; dan kehadiran dari perasaan negatif seperti depresi dan kecemasan. ${ }^{39}$ Alat ukur kebahagiaan ini tersusun atas 29 item dengan 6 pilihan jawaban yaitu: sangat tidak setuju, cukup setuju, sangat tidak setuju, sedikit setuju, cukup setuju, sangat setuju. Skor OHI terdapat 37 item valid, Skor OHI berada pada rentangan $29-174$. Skor OHI yang tinggi menunjukkan 174 skor OHI rendah menunjukkan 29. Berdasarkan hasil uji validitas kepada suami istri diketahui bahwa semua item valid dan dari hasil uji reabilitas diperoleh nilai Alpha Cronbach 0,886 .

\subsection{Prosedur Penelitian}

Pengambilan data penelitian ini dilakukan secara klasikal terhadap subyek yang memenuhi kriteria penelitian. Kedua subyek yaitu suami dan istri didatangi langsung di kediaman mereka. Setelah mendapat persetujuan dari kedua belah pihak untuk mengisi kuesioner, peneliti memberikan ketiga kuesioner yang telah disediakan.

\subsection{Analisis Data}

Berdasarkan analisis normalitas diperoleh kesimpulan bahwa variabel komunikasi interpersonal, pemaafan dan kebahagiaan adalah berdistribusi normal $(0,797,1,305$, dan 0,844). Untuk menguji hipotesis dilakukan Pengujian regresi ganda dengan menggunakan bantuan program SPSS versi 20.

\section{HASIL PENELITIAN}

\subsection{Deskripsi Variabel}

Subyek penelitian komunikasi interpersonal memiliki skor rata-rata $62,37 \mathrm{SD}=$ 14,32. Di antara kelompok subyek, subyek berpendidikan SMP memiliki komunikasi interpersonal yang tinggi dibandingkan dengan kelompok subyek dengan pendidikan SMA, Diploma, dan Sarjana. Dilihat dari usia pernikahan subyek

\footnotetext{
39 Argyle, M. \& Crossland, J. "Dimensions of Positive Emotions", The British Journal of Social Psychology, 26, 1987. 127-137.
} 
dengan usia pernikahan paling pendek (kurang dari 10 tahun) memiliki komunikasi interpersonal paling tinggi dibandingkan dengan kelompok usia lain.

Subyek penelitian pemaafan memiliki skor rata-rata 47,58 SD= 7,61. Di antara kelompok subyek, subyek berpendidikan Diploma memiliki pemaafan yang tinggi dibandingkan dengan kelompok subyek dengan pendidikan SMP, SMA, dan Sarjana. Dilihat dari usia pernikahan subyek dengan usia pernikahan paling lama (antara dari 20-30 tahun) memiliki pemaafan paling tinggi dibandingkan dengan kelompok usia lain.

Subyek penelitian kebahagiaan memiliki skor rata-rata 123,36 SD= 20,18. Diantara kelompok subyek, subyek berpendidikan SMA memiliki kebahagiaan yang tinggi dibandingkan dengan kelompok subyek dengan pendidikan SMP, Diploma, dan Sarjana. Dilihat dari usia pernikahan subyek dengan usia pernikahan paling pendek (kurang dari 10 tahun) memiliki kebahagiaan paling tinggi dibandingkan dengan kelompok usia lain.

Tabel 2: Perbandingan variabel penelitian berdasarkan karakteristik subyek

\begin{tabular}{lllllll}
\hline & \multicolumn{3}{c}{$\begin{array}{l}\text { Komunikasi } \\
\text { Interpersonal }\end{array}$} & \multicolumn{2}{c}{ Pemaafan } & \multicolumn{2}{c}{ Kebahagiaan } \\
\hline Karakterisktik Subyek & Mean & SD & Mean & SD & Mean & SD \\
\hline Pendidikan Suami Istri & & & & & & \\
\hline SMP & 63,69 & 14,37 & 46,25 & 7,36 & 117,19 & 25,39 \\
\hline SMA & 61,40 & 14,41 & 46,98 & 7,08 & 123,36 & 20,18 \\
\hline Diploma & 63,39 & 14,69 & 47,58 & 7,61 & 121,73 & 20,98 \\
\hline S1 & 62,15 & 13,81 & 47,55 & 9,37 & 120,58 & 21,29 \\
\hline Total & 62,37 & 14,33 & 47,21 & 7,64 & 121,87 & 20,98 \\
\hline
\end{tabular}

Usia Pernikahan

\begin{tabular}{lllllll}
\hline$\leq 10$ tahun & 63,13 & 13,28 & 47,75 & 7,39 & 124,30 & 19,20 \\
\hline $11-20$ tahun & 62,32 & 15,01 & 46,39 & 7,45 & 121,11 & 23,09 \\
\hline $21-30$ tahun & 61,15 & 14,25 & 48,82 & 8,51 & 119,94 & 16,82 \\
\hline Total & 62,37 & 14,33 & 47,21 & 7,64 & 121,87 & 20,98 \\
\hline
\end{tabular}




\subsection{Hubungan Antar Variabel}

Berdasarkan hasil analisis diperoleh hasil bahwa terdapat hubungan komunikasi interpersonal dengan pemaafan $(r=0,455, p=0,000)$ korelasi ini berada pada kategori cukup kuat. Terdapat hubungan positif antara komunikasi interpersonal dengan kebahagiaan $(r=0,658, p=0,000)$.

Tabel 3: Hubungan Antar Variabel

\begin{tabular}{llll}
\hline Variabel & KI & $\mathbf{P}$ & K \\
\hline Komunikasi Interpersonal (KI) & 1,00 & $0,455^{* *}$ & $0,658^{* *}$ \\
\hline Pemaafan $(\mathrm{P})$ & - & 1,00 & $0,578 * *$ \\
\hline Kebahagiaan $(\mathrm{K})$ & - & - & 1,00 \\
\hline
\end{tabular}

Keterangan: ${ }^{* *} \mathrm{p}<0,01$

\subsection{Uji Hipotesis}

Koefisien korelasi (R) yang dihasilkan sebesar 0,729 yang artinya terdapat hubungan yang kuat antara komunikasi interpersonal dan pemaafan dengan kebahagiaan suami istri. Koefisien determinasi $\left(\mathrm{R}^{2}\right)$ yang diperoleh sebesar 0,532. Nilai ini mempresentasikan kebahagiaan yang dipengaruhi oleh pemaafan dan komunikasi interpersonal yaitu sebesar 53,2\%, sedangkan pengaruh sisanya yaitu 46,8\% dipengaruhi oleh faktor lain selain pemaafan dan komunikasi interpersonal.

Tabel 4: Regresi antar variabel

\begin{tabular}{lllll}
\hline Model & R & R Square & $\begin{array}{l}\text { Adjusted R } \\
\text { Square }\end{array}$ & $\begin{array}{l}\text { Std. Error of } \\
\text { the Estimate }\end{array}$ \\
\hline 1 &, $729^{\mathrm{a}}$ &, 532 &, 527 & 14,431 \\
\hline
\end{tabular}

a. Predictors: (Constant), Pemaafan, Komunikasi Interpersonal 


\section{PEMBAHASAN PENELITIAN}

Berdasarkan pada pengujian di atas diketahui bahwa kebahagiaan suami istri berhubungan dengan komunikasi interpersonal dan pemaafan. Terdapat hubungan yang signifikan antara hubungan komunikasi interpersonal dengan pemaafan. Kategori dari korelasi ini termasuk dalam kategori yang cukup kuat. Karena koefisien korelasi bertanda positif, maka dapat dikatakan bahwa semakin efektif komunikasi yang terjalin antara suami istri maka pemaafan yang akan diberikan akan semakin baik juga. Selain pemaafan, pelatihan komunikasi interpersonal perlu diupayakan sebagai solusi yang penting untuk memulihkan komunikasi yang bermasalah sehingga menjadi harmonis. ${ }^{40}$

Pemaafan memainkan peran penting dalam menjaga dan memperbaiki komunikasi interpersonal. Dalam hal ini, pemaafan dapat terjadi setelah ada diskusi antara kedua belah pihak. Pasangan cenderung menggunakan komunikasi interpersonal dalam menyelesaikan sebuah masalah atau bernegosiasi. ${ }^{41}$ Pihak yang melakukan kesalahan akan menawarkan pemaafan bersyarat ketika hubungan sebelumnya memuaskan, dan oleh karena itu perlu perbaikan, tetapi hanya jika mereka yakin bahwa kesalahan tersebut tidak akan terjadi lagi. Pemaafan bersyarat dilakukan secara khusus dan biasanya dilakukan oleh pasangan yang menilai pelanggaran tersebut negatif. ${ }^{42}$

Dalam penelitian ini, subyek yang diteliti adalah subyek dengan masa perkawinan lebih dari lima tahun. Pertimbangan ini didasarkan bahwa perkawinan memerlukan penyesuaian antara pasangan yang terlibat secara langsung maupun tidak langsung mempengaruhi besar kecilnya kebahagiaan dalam perkawinan. Selama tahun pertama dan kedua perkawinan pasangan suami istri biasanya harus menyesuaikan satu sama lain, terhadap anggota keluarga masing-masing dan teman-temannya. Pada proses penyesuaian, sering timbul ketegangan emosional dan khususnya terjadi pada anggota keluarga muda. Diharapkan pasangan suami istri yang masa pernikahannya lebih dari lima tahun telah melewati masa penyesuaian.

Dalam hubungan antara komunikasi interpersonal dan kebahagiaan, diperoleh adanya hubungan yang signifikan. Kategori dari korelasi ini termasuk dalam kategori kuat. Maka, dapat dikatakan bahwa semakin baik komunikasi interpersonal yang terjalin antara suami istri maka kebahagiaan akan semakin meningkat. Komunikasi interpersonal berperan penting dalam pernikahan.

\footnotetext{
${ }^{40}$ O'Donohue, W., \& Crouch, J. L. "Marital Therapy and Gender-linked Factors in Communication", Journal of Marital and Family Therapy, 22, 1996. 87-101.

${ }^{41}$ Waldron,V. L., \& Kelley, D. L. Communicating Forgiveness, (Thousand Oaks, CA: Sage, 2008).

42 Waldron, V. R., \& Kelley, D. L. "Forgiving Communication as A Response to Relational Transgressions, Journal of Social and Personal Relationships, 22, (2005). 723-742.
} 
Kesulitan berkomunikasi paling sering dialami oleh pasangan yang sudah menikah. ${ }^{43}$ Penelitian yang lain juga menyebutkan bahwa kesulitan komunikasi interpersonal menjadi masalah yang paling sering dikeluhkan oleh banyak pasangan pada saat pasangan melakukan terapi. ${ }^{44}$ Masalah komunikasi interpersonal juga disebabkan karena kurangnya keterampilan dalam berkomunikasi dengan pasangan sehingga terjadi kesalahan dalam menerima informasi yang berdampak tidak mengertinya salah satu pasangan akan maksud yang disampaikan. Hal ini bisa menjadi pemicu kemarahan dan timbulnya sakit hati pada pasangan. Pemaafan memberikan peran yang sangat penting supaya komunikasi interpersonal dapat kembali berjalan dengan efektif dan hubungan suami istri menjadi harmonis. ${ }^{45}$

Harmonis tidaknya hubungan suami istri tergantung dari kondisi komunikasi interpersonal yang terjalin. Hubungan yang harmonis tersebut dapat terjalin dengan baik melalui komunikasi interpersonal yang efektif antara suami dan istri. Kebahagiaan suami istri merupakan suatu perwujudan kondisi kualitas komunikasi interpersonal yang efektif. Komunikasi interpersonal merupakan awal dari keharmonisan. Pernyataan tersebut mengandung arti bahwa keharmonisan akan sulit terwujud tanpa adanya komunikasi interpersonal yang efektif. Begitu pula untuk mewujudkan suatu pernikahan yang harmonis akan sulit tanpa adanya komunikasi interpersonal yang baik antara suami dan istri. Agar suasana hubungan yang baik dapat terwujud, diperlukan suasana yang hangat, penuh pengertian, penuh kasih sayang satu dengan lainnya agar dapat menciptakan suasana yang akrab dan ceria diantara suami dan istri. Dasar dari terciptanya suasana hubungan ini adalah terciptanya komunikasi yang efektif antara suami dan istri.

Penelitian terbaru mengungkapkan bahwa mereka yang memiliki pemaafaan yang tinggi akan lebih bahagia dalam berhubungan dengan pasangan mereka. Temuan ini menggaris bawahi pentingnya pemaafan dalam kehidupan berumah tangga. Temuan tersebut juga menunjukkan bahwa pemaafan yang tinggi meningkatkan pemahaman terhadap satu sama lain ${ }^{46}$

Hal yang terpenting dari penelitian ini adalah diketahuinya hubungan yang signifikan antara komunikasi interpersonal dan pemaafan secara bersama-sama dengan

43 Cunningham, J. D., Braiker, H.,\& Kelley, H. "Marital Status and Sex Differences in Problems Reported by Married and Cohabitating Couples", Psychology of Women Quarterly, 6, 1982. 415427.

44 Geiss, S. K., \& O'Leary, K.D. "Therapist Ratings of Frequency and Severity of Marital Problem: Implication for Research. Journal of Marriage and Family Therapy, 7, 1981. 515-520.

45 O’Donohue, W., \& Crouch, J. L. “Marital Therapy and...

46 Allemand, M. Amberg, I, Zimprich, D. \& Fincham, F. D. "The Role of Trait Forgiveness and Relationship Satisfaction in Episodic Forgiveness", Journal of Social and Clinical Psychology, 26, (2), 2007. 199-217 
kebahagiaan suami istri. Kategori dari korelasi ini termasuk pada kategori kuat. Semakin tinggi tingkat komunikasi interpersonal dan pemaafan pasangan maka semakin tinggi pula tingkat kebahagiaan yang dicapai dalam sebuah perkawinan.

Penelitian sebelumnya menemukan adanya hubungan yang dapat dipercaya antara pemaafan dan kebahagiaan dalam perkawinan. Pemaafan sebagai variabel yang berkontribusi memberikan kebahagiaan dalam pernikahan dapat memprediksi perilaku keseluruhan terhadap pasangan dan menunjukkan respon dan pembalasan yang baik atas sebuah pelanggaran. Selain itu, pemaafan sepenuhnya dimediasi oleh tanggung jawab atas perilaku pasangan dan ditunjukkan oleh perilaku pasangan yang lain. ${ }^{47}$ Sebagai sebuah aspek dasar dalam semua jenis hubungan, pemaafan memiliki potensi untuk memfasilitasi ilmu yang lebih terintegrasi dalam hubungan dekat, menyatakan bahwa pemaafan berkaitan dengan komunikasi dan resolusi konflik.

Suami istri yang mampu melakukan komunikasi interpersonal dengan efektif ditandai dengan adanya hubungan interpersonal yang baik pula antara kedua belah pihak. Hubungan interpersonal tersebut tidak hanya ditentukan oleh sering atau tidaknya individu melakukan komunikasi, akan tetapi ditentukan juga oleh mutu dari komunikasi tersebut. Komunikasi yang baik adalah komunikasi yang efektif, yang ditunjukkan oleh 5 (lima) sikap positif dengan ciri-ciri adanya rasa saling terbuka, empati, saling mendukung, sikap positif, dan kesetaraan. Apabila pasangan suami istri saling menunjukkan sikap yang positif terhadap pasangannya maka komunikasi interpersonal dapat berjalan secara efektif. Terciptanya komunikasi yang efektif diantara suami istri membuat hubungan interpersonal menjadi baik sehingga dapat mewujudkan kebahagiaan dalam pernikahan yang ditunjukkan dengan adanya rasa saling mengerti, saling menerima, saling menghargai, saling percaya, dan saling mencintai antara suami dan istri. Hal tersebut menunjukkan bahwa pasangan suami istri yang mampu bersikap positif dalam melakukan komunikasi interpersonal efektif dapat mendukung terwujudnya kebahagiaan dalam pernikahan. Sebaliknya, jika pasangan suami istri menunjukkan sikap negatif seperti saling curiga terhadap pasangannya maka hubungan interpersonalnya menjadi renggang dan mengakibatkan komunikasi interpersonal antara suami dan istri menjadi tidak efektif dan kebahagiaan akan sulit terwujud.

Komunikasi interpersonal yang efektif dapat membantu pasangan saling memahami kebutuhan, apa yang menjadi harapannya, dan bagaimana dia berusaha memenuhi harapan anda, dan membantu hubungan untuk tumbuh. Memahami kekuatan dan kelemahan, aspirasi dan kekhawatiran serta ketakutan dan harapan seseorang membuat hidup dengan pasangan menjadi lebih mudah dan dengan demikian hubungan yang harmonis akan tercipta. Sebuah penelitian menunjukkan bahwa memahami

${ }^{47}$ Fincham, F.D., \& Beach, S.R.H. "The Kiss of the Porcupines: Fromattributing Responsibility to Forgiving", Personal Relationships, 7, 2000. 1-23 
pasangan adalah prediktor terkuat dari pernikahan. ${ }^{48}$ Ketika kualitas dan kuantitas komunikasi semakin menurun, maka kebencian dan dendam atas apa yang menimpa hidup masing-masing juga akan timbul. Pada masa-masa seperti ini, pemaafan biasanya semakin sulit terjadi karena pasangan cenderung tidak mau berkomunikasi satu sama lain. Mereka menghindari masalah yang sedang terjadi, cenderung lari dari kenyataan, dan menilai diri sendiri maupun pasangannya menurut persepsinya masing-masing

\section{KESIMPULAN}

Hasil penelitian ini mendukung ketiga hipotesis penelitian yang diajukan, yaitu: adanya hubungan positif antara komunikasi interpersonal dengan kebahagiaan, adanya hubungan positif antara pemaafan dengan kebahagiaan, adanya hubungan positif antara komunikasi interpersonal dan pemaafan dengan kebahagiaan. Hasil ini menandakan bahwa apabila komunikasi interpersonal yang dilakukan efektif maka pemaafan suami istri akan meningkat dan kebahagiaan pernikahan akan tercapai.

Adapun saran-saran yang dapat diberikan peneliti berdasarkan dari hasil penelitian ini yaitu saran praktis dan saran bagi peneliti selanjutnya. Saran praktis salah satunya bagi pasangan suami istri agar lebih sering meluangkan waktu untuk bertemu dan saling berkomunikasi secara intim dengan pasangannya untuk meng-hindari munculnya perasaan negatif seperti rasa saling curiga terhadap pasangan yang dapat menimbulkan masalah. Ditambah lagi, sebaiknya suami bisa berlatih memahami dan saling bekerjasama untuk memecahkan permasalahan dalam rumah tangga sehingga dapat saling memaafkan ketika terjadi kesalahpahaman dalam berkomunikasi sehingga tujuan memperoleh kebahagiaan dapat tercapai.

Saran bagi peneliti selanjutnya yang tertarik untuk melihat hubungan antara komunikasi interpersonal dan pemaafan terhadap kebahagiaan suami istri, diharapkan dapat menyempurnakan penelitian ini dengan menambah faktor-faktor lainnya yang berpengaruh terhadap kebahagiaan suami istri. Faktor-faktor lain yang dapat mempengaruhi kebahagiaan suami istri seperti faktor psikologis, kesehatan, seksual, sosial-ekonomi, dan keluarga. []

\footnotetext{
${ }^{48}$ Acitelli, L. K., Douvan, E., \& Veroff, J. "Perceptions of Conflict in the First Year of Marriage: How Important are Similarity and Understanding?", Journal of Social and Personal Relationships, 10, 1993. 5-19.
} 


\section{DAFTAR PUSTAKA}

Acitelli, L. K., Douvan, E., \& Veroff, J. (1993). "Perceptions of Conflict in the First Year of Marriage: How Important Are Similarity and Understanding?”, dalam Journal of Social and Personal Relationships, 10, 5-19.

Afifi,W. A., Falato,W. L., \& Weiner, J. L. (2001). “Identity Concerns Following A Severe Relational Transgression: The Role of Discovery Method for the Relational Outcomes of Infidelity”, dalam Journal of Social and Personal Relationships, 18, 291-308.

Allemand, M. Amberg, I, Zimprich, D. \& Fincham, F. D. (2007). "The Role of Trait Forgiveness and Relationship Satisfaction in Episodic Forgiveness", dalam Journal of Social and Clinical Psychology, 26, (2), 199-217

Argyle, M. \& Crossland, J. (1987). "Dimensions of Positive Emotions”, dalam The British Journal of Social Psychology, 26, 127-137.

Boon, S.D., \& Sulsky, L.M. (1997). "Attribution of Blame and Forgiveness in Romantic Relationships: A Policy-Capturing Study”, dalam Journal of Social Behavior and Personality. 12. 19-44.

Burleson, Brant R; Denton, Wayne H (1997). "The Relationship between Communication Skill and Marital Satisfaction: Some Moderating Effects”, dalam Journal of Marriage and the Family; 59, 4;884-902

Cunningham, J. D., Braiker, H.,\& Kelley, H. (1982). "Marital Status and Sex Differences in Problems Reported by Married and Cohabitating Couples", dalam Psychology of Women Quarterly, 6, 415-427.

Darby, B.W. and Schlenker, B. R. (1982). "Children Reactions to Apologies”, dalam Journal of Personality and Social Psychology, 43 (4), 742-753.

Diener, E., Gohm, C., Suh, E., \& Oishi, S. (1998). "Similarity of the Relations between Marital Status and Subjective Well-being Across Cultures”, dalam Journal of Cross-Cultural Psychology, 31 (4), 419-436.

Diener, E., Scollon, C.N., \& Lucas, R.E. (2003). The Evolving Concept of Subjective Well-being: the Multifaceted Nature of Happiness. Advances in Cell Aging and Gerontology, 15, 187-219.

Diener \& Oishi. (2005). "Subjective Well-being: the Science of Happiness and Lifesatisfaction”, dalam C. R Synder \& S. J Lopez (Eds), Handbook of Possitive Psychology, (2nd ed), (pp. 63-73). New York, NY: Oxford University press.

Effendy (2002). Hubungan Masyarakat Suatu Study Komunikologis. Bandung: Remaja Rosdakarya. 
Enright, R. D., Gassin, E. A., \& Wu, C. (1992). "Forgiveness: A development view”, dalam Journal of Moral Education, 2, 99-114.

Fincham, F. D. (2000). "The kiss of the Porcupines: From Attributing Responsibility to Forgiving”, dalam Personal Relationships, 7, 1-23.

. (2002). "Forgiveness in Marriage: Implications for Psychological Aggression and Constructive Communication", dalam Personal Relationships, 9, 239-251.

\& Davila, J. (2004). "Forgiveness and Conflict Resolution in Marriage”, dalam Journal of Family Psychology, 18, 72-81.

Freedman, S. R., \& Enright, R. D. (1996). "Forgiveness as an Intervention Goal with Incest Survivors”, dalam Journal of Consulting and Clinical Psychology, 64, 983-992.

Geiss, S. K., \& O’ Leary, K.D. (1981). Therapist Ratings of Frequency and Severity of Marital Problem; Implication for Research, dalam Journal of Marriage and Family Therapy, 7, 515-520.

Hurlock, EB (2000). Psikologi Perkembangan; Suatu Pendekatan Sepanjang Rentang Kehidupan. Edisi kelima Jakarta: Erlangga.

Johnson, M. P. (1995). "Patriarchal Terrorism and Common Couple Violence; Two Forms of Violence against Women", dalam Journal of Marriage and the Family, 57,283-294.

Karremans, J. C., \& Van Lange, P. A. M. (2004). "Back to Caring after Being Hurt: The Role of Forgiveness", dalam European Journal of Social Psychology, 34, 207-227.

McKenry, B. C., Julian, T. W., \& Gavazzi, S. M. (1995). “Toward a Biopsychosocial Model of Domestic Violence", dalam Journal of Marriage and Family. 57, 307-320.

Maltby J, Day L, \& Louise Barber, (2005). "Forgiveness And Happiness. The Differing Contexts Of Forgiveness Using The Distinction Between Hedonic And Eudaimonic Happiness”, dalam Journal of Happiness Studies 6,1-13

McCullough, M. E.,\& Witvliet, C. V. (2002). “The Psychology of Forgiveness”, dalam C. R. Snyder \&S. L. Lopez (Eds.), Handbook of Positive Psychology, NewYork: Oxford University Press.

McCullough, M. E. (2000). "Forgiveness as Human Strength: Theory, Measurement, and Links to Well-Being, dalam Journal of Social and Clinical Psychology, 19(1), 43-55.

, Wortington, E. L., Rachal, K.C., Sandage, S. J., Brown, S.W., \& Hight, T. L. (1998). "Interpersonal Forgiving in Close Relationships: II. Theoritical 
Elaboration and Measurement”, dalam Journal of Personality and Social Psychology, 75, (6), 1586-1603.

O’Donohue, W., \& Crouch, J. L (1996). “Marital Therapy and Gender-Linked Factors in Communication”, Journal of Marital and Family Therapy, 22, 87-101.

Okun, B. F. (1991). Effective Helping, Interviewing, and Counseling Techniques ( $3^{\text {rd }}$ ed.), Monterey, CA: Brooks/Cole.

Papalia, D.E., Olds, S.W., \& Feldman, R.D. (2004). Human Development, New York: McGraw

Ryan, R. M., \& Deci, E. L. (2001). “On Happiness and Human Potentials: A Review of Research on Hedonic And Eudaimonic Well-Being”, dalam Annual Review of Psychology,52, 141-166.

Sarafino, E.P. (2006). Health Psychologi: Biopsychology Interaction. Ed. V. USA: John Wiley \& Sons.

Sarwono, P.(2009). Statistik Itu Mudah: Panduan Lengkap untuk BelajarKomputasi Statistik Menggunakan SPSS 16, Yogyakarta: Penerbit Universitas Atma Jaya.

Smedes, L. B. (1984). Forgive and Forget: Healing the Hurts We Don't Deserve, New York: Harper \& Row.

Terman, L. M. (1938). Psychological Factors in Marital Happiness. New York: McGraw-Hill.

Vardiansyah, Dani.(2004). Pengantar Ilmu Komunikasi, Bogor: Ghalia Indonesia.

Waldron,V. L., \& Kelley, D. L. (2008). Communicating Forgiveness, Thousand Oaks, CA: Sage. , (2005). "Forgiving Communication as A Response to Relational Transgressions”, dalam Journal of Social and Personal Relationships, 22, 723-742.

Wisnuwardhani, D \& Fatmawati, Mashoedi Sri. (2012). Hubungan Interpersonal. Edisi I, Jakarta: Salemba Humanika.

Worthington, E.L., Jr. (2003). Forgiving and Reconciling: Bridges to wholeness and hope. Downers Grove, IL: InterVarsity Press. 